\title{
Effects of Continuous Annealing Conditions on Mechanical Properties of Drawing Quality High Strength Steel Sheet
}

\author{
Osamu Akisue, Teruaki Yamada, Shigeru Ueda, and Kikuo Takasmina
}

\section{Synopsis:}

Effects of continuous annealing conditions on mechanical properties of drawing quality high strength steel sheet were studied using the continuous annealing heat cycle simulator which had been developed by the authors.

Continuous annealing conditions which were studied are as follows:

(1) Cooling rate before over aging. (2) Starting temperature of cooling in the cases of AcC: (accelerated cooling) method and W.Q (water quenching) method. (3) End temperature of cooling in the case of $\mathrm{AcC}$ method. At the same time, changes of the amount of carbon in solution and carbide precipitation during heat treatments were studied.

As a result of this study, it was made clear that the most desirable heat cycle for drawing quality and non aging high strength steel sheet consisted of slow cooling of about $7^{\circ} \mathrm{C} / \mathrm{s}$ from soaking temperature to $675^{\circ} \mathrm{C}$, accelerated cooling of about $100^{\circ} \mathrm{C} / \mathrm{s}$ from $675^{\circ} \mathrm{C}$ to $400^{\circ} \mathrm{C}$ and over aging at $400^{\circ} \mathrm{C}$. In this annealing condition, most of the fine carbides precipitated on grain boundaries and the amount of carbon in solution decreased in short over aging time.

\section{1. 緒言}

最近の白動車においては, 燃料費の低減のたぬの車体 軽坒化，衝突安全の確保および耐デント性の问上が計ら れてきており，そのために高張力鋼板が多星に使用され るよらになつてきた。

この目的に用いられるけ動本用岁張打冷延鋼板として 借えていなけ机ばならない特性は，必装な高張力に加え て良好なソ゚レ久加工性，溶接性，波学特性，塗装耐食性 などである。なかでも，最も使用が多くなつてきている 外以板用の 35 40 kgf $/ \mathrm{mm}^{2}$ 級の加工用拈上び絞り加工 用高張力鋼板では，良好なプレス加工性，形状凍結性に 加えてストレッチャー・ストレインの発尘しない性質も 供えていることが必要である。このよらな諸特性をバラ ン火よく備えた鋼板を供給するのが鉄鋼メーカーにとつ て重要な課題である。

著者らは，35 40 kgf $/ \mathrm{mm}^{2}$ 級の 的車用外内板问以 の加工用および深絞り加工用の高張力冷延鋼板を連続焼 鈍法にて製造する方法を研究し，箱焼鈍材の短所を補い つつ，箱焼鈍材並のソ゚レス㞦亡性を得る連続焼鈍才法を
開発してきた。

従来の連続燒鈍うj法:1) 4)には鋼板の忉質に及ばす影響 にそれぞれの特徴がある。その材質上の特徽は連続焼鈍

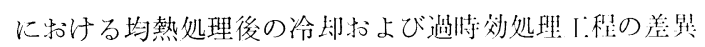
によつて生じる5) 7).

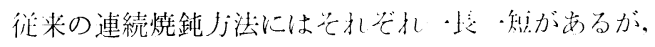

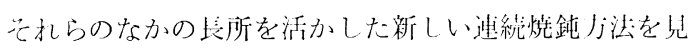
出与ための治金学的な研究を重权てきた。本淪文におい ては，特に材質に及ぼす連緮焼鈍条件:の影催についての ベる.

\section{2. 一次急冷速度の影響}

連続焼鈍によつて製造される加工用高张冷延鋼板抒 よび.一般の加工用冷延鋼板の基本的な材質特性（降伏 点, 伸び，時効性，焼付硬化性など）は，連続焼鈍の均 熱処理後の冷却と過時効処理の条件によつてほぼ汱定さ れる。

まず，均熱に続いて冷却の後は再加熱をおこなおない 連続燒鈍万法において，冷却速度が材質に及ぼす影響を 調査した。

枴利 56 作 10 月 15 月受付 (Received Oct. 15, 1981)

* 新日本製鉄 (株) 広烟製鉄所 理博 (Hirohata Works, Nippon Steel Corp., 1 Fuji-cho Hirohata-ku Himeji 671-11)

*2 新日本製鉄 (株) 広烟製鉄所 (Hirohata Works, Nippon Steel Corp.) 


\section{$2 \cdot 1$ 実験方法}

Table 1 には実験に用いたP添加-A1 キルド鋼板の化 学成分と熱延条件を示す。この熱延板を冷間压延により て板厚 $0.80 \mathrm{~mm}$ の泠延板にし，熱処理は著者らが開発 した連続焼鈍熱サイクル・シミュレーターによつて沶こ なつた。

Fig. 1 に示すよらに絞り加工用高張力鋼板としての 高い $r$ 值を得るために $850^{\circ} \mathrm{C} て ゙ ~ 40 \mathrm{~s}$ 間の均熱処理をし て，その後均熱中に生じた一部のオーステナイト粒をゆ つくりフェライト粒に変態させることと, 固溶炭素量を 制御するために 8 9) 均熱温度から $675^{\circ} \mathrm{C}$ までは徐冷し た。引引続いて $400^{\circ} \mathrm{C}$ の過時効処理温度までの間を 3 $200^{\circ} \mathrm{C} / \mathrm{s}$ の範囲で泠却速度を変光 $400^{\circ} \mathrm{C}$ で $120 \mathrm{~s}$ の過時 効処理を括こないその後 $100^{\circ} \mathrm{C} / \mathrm{s}$ で室温まで泠却した。 熱処理材については内部摩摖法によつて固溶炭素量の 測定およびセメンタイト等の炭化物の析出分散状態の観 察を扮こなつた．更に $1.0 \%$ の調質压延をして $100^{\circ} \mathrm{C}$ で $1 \mathrm{~h}$ の時効処理を施した試料についてはJIS-5 号試験 片によつて材質調査をおこなつた.

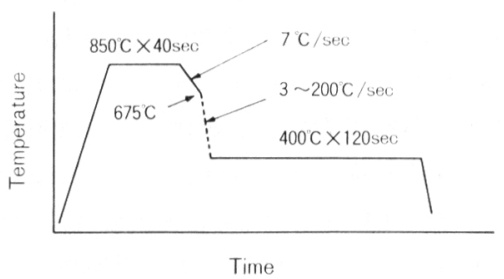

Fig. 1. Heat cycles for study on the effect of cooling rate. The cooling rate is from 3 to $200^{\circ} \mathrm{C} / \mathrm{s}$.

\section{$2 \cdot 2$ 実験結果および考察}

Fig. 2 は $400^{\circ} \mathrm{C}$ での過時効処理が $120 \mathrm{~s}$ の場合の冷 却速度の固溶炭素量への影響を示す。過時効処理後の固 溶炭素量はこの一次急冷速度によつて大きく変わり, 泠 却速度が遅い場合には固溶炭素量は非常に多くなる。冷 却速度が $3,7^{\circ} \mathrm{C} / \mathrm{s}$ の場合にはそれぞれ $32,27 \mathrm{ppm}$ 岁 る固溶炭素量が， $100,200^{\circ} \mathrm{C} / \mathrm{s}$ と速くなると固溶炭素 量以約 $10 \mathrm{ppm}$ 之 $400^{\circ} \mathrm{C}$ での平衡炭素量 ${ }^{10)}$ に近い值ま で低下して過時効処理が非常に効率的に進行することが わかる。

Photo. 1 は一次急冷速度を 3 から $200^{\circ} \mathrm{C} / \mathrm{s}$ 束で变化 させ， $400^{\circ} \mathrm{C} て ゙ ~ 120 \mathrm{~s}$ の過時効処理をおこなつた試料の セメンタイトの析出状態を示す. $3^{\circ} \mathrm{C} / \mathrm{s}$ の徐冷の場合は セメンタイトの析出密度が最も低く, 大半は結晶粒界の

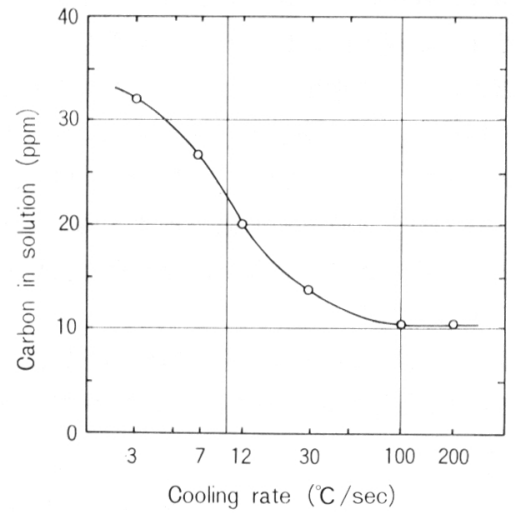

Fig. 2. Effect of cooling rate on the amount of carbon in solution. Over aging condition is $400^{\circ} \mathrm{C} \times 120 \mathrm{~s}$

Table 1. Chemistry and hot rolling conditions of steel.

\begin{tabular}{|c|c|c|c|c|c|c|c|c|}
\hline \multicolumn{6}{|c|}{ Chemistry $(\%)$} & \multicolumn{3}{|c|}{ Hot rolling conditions } \\
\hline C & $\mathrm{Mn}$ & $\mathrm{P}$ & $\mathrm{S}$ & sol. Al & T. $\mathrm{N}$ & $\begin{array}{l}\text { Finishing temperature } \\
\qquad\left({ }^{\circ} \mathrm{C}\right)\end{array}$ & $\begin{array}{l}\text { Coiling temperature } \\
\left({ }^{\circ} \mathrm{C}\right)\end{array}$ & $\begin{array}{l}\text { Thickness of hot band } \\
(\mathrm{mm})\end{array}$ \\
\hline 0.034 & 0.14 & 0.052 & 0.005 & 0.060 & 0.0019 & 875 & 735 & 3.5 \\
\hline
\end{tabular}

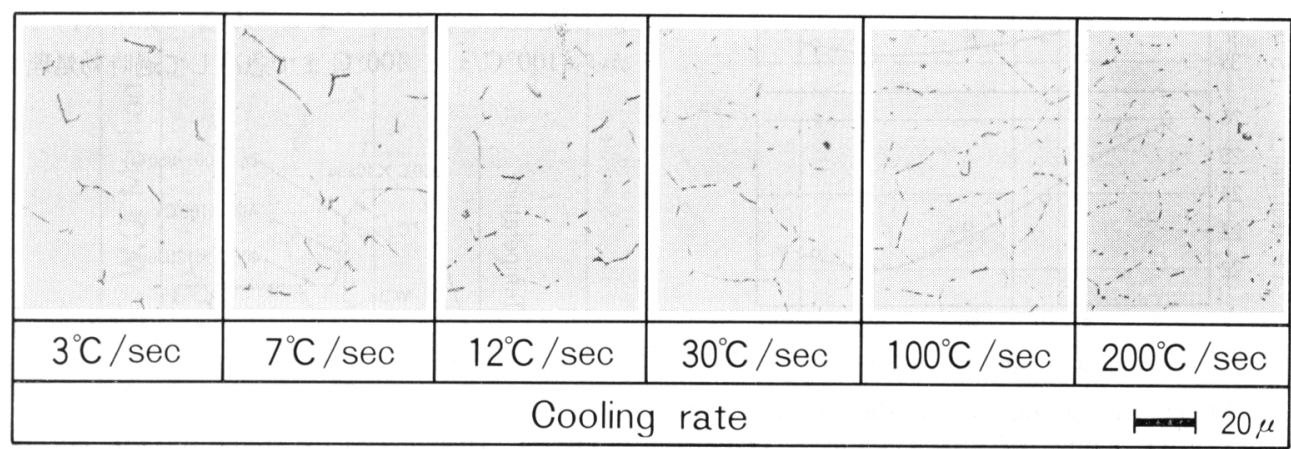

Photo. 1. Effect of cooling rate on carbide precipitation. 
重点にやや大きく成長して析出している，冷却速度が 速くなるに従つてセメンタイトの析出場所は結晶粒界の 三重点から結晶粒界に変わり, そのサイズは小さくなり 密度は高くなる。冷却速度が $100,200^{\circ} \mathrm{C} / \mathrm{s}$ になるとセ メンタイトの大部分は結晶粒界に片状の形をして点列状 に多数析出するようになるが結晶粒内の析出はほとんど ない.

このようにセメンタイトの析出場所は主として結唱䊉 界であるが，析出物の密度は冷却速度によつて大きく变 化する. 析出物の密度が変わるといらことは過時効処理 中に括ける炭素の必要拡散距離が大きく变わるというこ とであり，冷却速度を $100 ， 200^{\circ} \mathrm{C} / \mathrm{s}$ にすると炭素の析 出に要する距離が短くなり Fig. 2 に示したよらに固溶 炭素量は短時間で低減することになる。

Fig. 3 は $400^{\circ} \mathrm{C} て ゙ ~ 120 \mathrm{~s}$ の過時効処理をした場合の 一次急冷速度が機械的性質に及ぼす影響を示す。加工用 高張力鋼板にとつて重要であるプレス加工性および形状 凍結性の指標である, 降伏点 (降伏比), 伸びおよびス トレッチャー・ストレインの指標となる降伏点伸びを $100^{\circ} \mathrm{C} \times 1 \mathrm{~h}$ の人工時效後の值で示す. 鋼板が央際にプ レ以加亡さ机るときには時効がかなり進んでいるのが通 常であるからである。

Fig. 2 の固溶炭幸量の変化之機俄们性質はよく対心 しておう, 固溶炭素量が多くなる徐冷の場合は降伏点

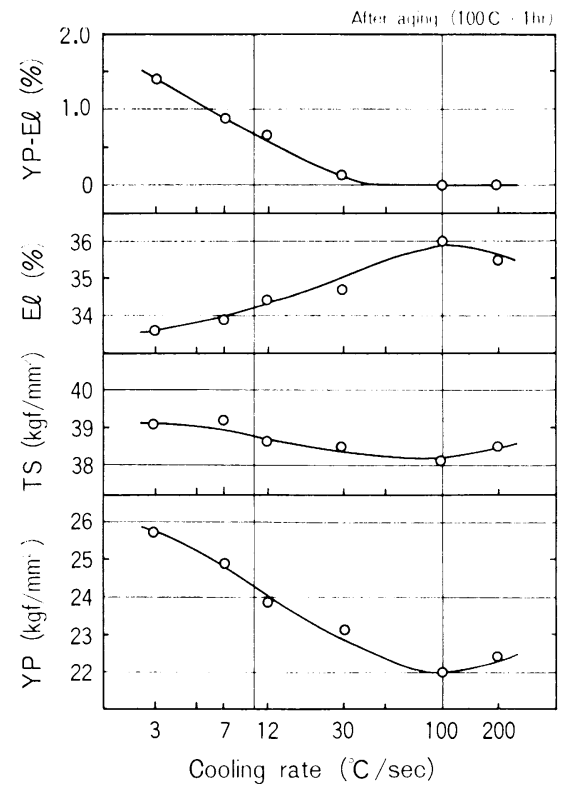

Fig. 3. Effects of cooling rate on the mechanical properties after aging of $100^{\circ} \mathrm{C} \times 1 \mathrm{~h}$. Over aging condition is $400^{\circ} \mathrm{C} \times 120 \mathrm{~s}$.
（降伏比）が高く伸びが低くなり降伏点伸びは高くなる. 冷却速度が $100^{\circ} \mathrm{C} / \mathrm{s}$ になると降伏点（降伏比）は小さ く伸びは大きくなり，しかも降伏点伸びはゼ口になり実 質的飞非時効性鋼板が得られる.

\section{3. 一次急冷開始温度の影響}

加工用高張力鋼板を連続焼鈍によつて製造するには一 次急冷速度を $100^{\circ} \mathrm{C} / \mathrm{s}$ 前後にすることが極めて重要で あることが前章でわかつた．本章では尖験手段としての 水冷による急冷の方法 (water quenching method，以 下 W. Q 法） と約 $100^{\circ} \mathrm{C} / \mathrm{s}$ の急冷を採用する方法 (accelerated cooling method, 以下 AcC 法) の場合に ついて，それぞれの一次急冷開始温度の影響について述 ベる.

\section{$3 \cdot 1$ 実験方法}

実験は Table 1 に示した熱延板を $0.80 \mathrm{~mm}$ に冷間 比延し，それに Fig. 4 と示す熱処理を施しておこなつ た.

W. Q 法ならびに・次急冷の終点温度を過時効温度で ある $400^{\circ} \mathrm{C}$ に終点温度制御した $\mathrm{ACC}$ 法において, 850 ${ }^{\circ} \mathrm{C}$ の均熱温度から…次急冷開始温度 $\left(T_{\mathrm{Q}}\right)$ までの間 は $7^{\circ} \mathrm{C} / \mathrm{s}$ で徐冷しその後は水中冷却拈よび $100^{\circ} \mathrm{C} / \mathrm{s}$ で泠却した，急冷開始温度は $850^{\circ} \mathrm{C}$ から $400^{\circ} \mathrm{C}$ までの 間で多くの温度を選んだ。 W. Q 法の場合は $T_{\mathrm{Q}}$ から 水冷によつて $30^{\circ} \mathrm{C}$ まで急冷し, その温度で $5 \mathrm{~s}$ 保持し た後 $20^{\circ} \mathrm{C} / \mathrm{s}$ の速度で $400^{\circ} \mathrm{C}$ まで侢加熱して $60 \mathrm{~s}$ の 過時効処理をした，AcC 法の場命は $400^{\circ} \mathrm{C}$ に急冷の終 点温度制御し，そのまま続いて $120 \mathrm{~s}$ の過時効処理をし た. 得られた試料の固溶炭素量, 岑化物の析出状態, 1.0 $\%$ の調質压延と $100^{\circ} \mathrm{G} て ゙ 1 \mathrm{~h}$ の㭙効处理後の機械的性 質を調査し一次急冷開始温度の影響を調べた。

\section{$3 \cdot 2$ 実験結果および考察}

Fig. 5 飞W.Q 法拉よび AcC 法での固溶岑素量に 及ぼす一次急冷開始温度の影響を示与。AcC 法の場合 は均熱温度から $675^{\circ} \mathrm{C}$ まで $7^{\circ} \mathrm{C} / \mathrm{s}$ で徐冷し，その温度 から $100^{\circ} \mathrm{C} / \mathrm{s} て ゙ ~ 400^{\circ} \mathrm{C}$ まで急冷して過時効処理をする

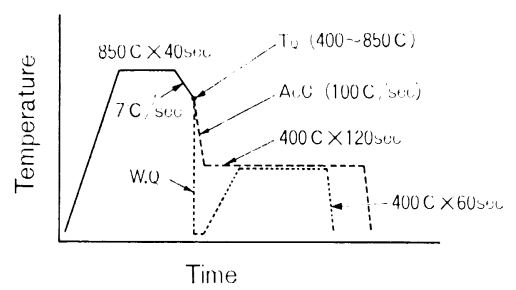

Fig. 4. Heat cycles for study on the effects of the starting temperature $\left(T_{\mathrm{Q}}\right)$ of cooling. 


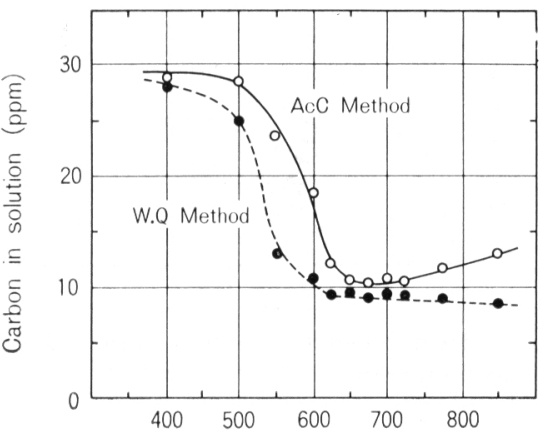

Starting temperature of cooling $\left({ }^{\circ} \mathrm{C}\right)$

Fig. 5. Effect of the starting temperature $\left(T_{\mathbf{Q}}\right)$ of cooling on the amount of carbon in solution.

とき㵵も固溶炭素量は少なくなる。 $T_{\mathrm{Q}}$ が $675^{\circ} \mathrm{C}$ 上 りも高くなる之固溶炭素量は若干増加する。また， $T_{\mathrm{Q}}$ が $625^{\circ} \mathrm{C}$ より低くなり徐冷の時間が長くなると急激に 固溶炭素量は多くなり，Fig. 2 飞捄ける徐冷の場合之 同じく固溶炭素量は約 $28 \mathrm{ppm}$ にもなる。

$\mathrm{W} . \mathrm{Q}$ の場合には，固溶炭素量は $T_{\mathrm{Q}}$ が $625^{\circ} \mathrm{C}$ 以上 で AcC 法の場合よりもやや少なくなり, また，高温に なつて子増加はしない， $T_{Q}$ が $600^{\circ} \mathrm{C}$ より低くなると $\mathrm{AcC}$ 法の場合と同様に固溶炭素量は急激に増加する.

$T_{\mathrm{Q}}$ が $400^{\circ} \mathrm{C}$ の場合でも過時効処理時間が $60 \mathrm{~s}$ 之短 いにもかかわらず，Fig. 1 に示した徐冷サイクルの場 合と同程度の固溶炭素量となる。

Photo. 2 飞 AcG 法拈よびW.Q 法に特ける炭化物
の析出分散状態を示す. AcG 法の場合はセメンタイト の大部分は結晶粒界に析出し $T_{\mathrm{Q}}$ が $^{\circ} 675^{\circ} \mathrm{C}$ の場合の析 出物の密度が最も高い。 $T_{\mathrm{Q}}$ が $850^{\circ} \mathrm{C}$ の場合は，850 ${ }^{\circ} \mathrm{C}$ でのフェライト粒内の炭素の固溶量が少なくなるた めか炭化物量はやや少なく，かつ小さな炭化物となつて 粒界に点列状に析出与る。 その結果固溶炭素量は若干増 加するものと考党られる． $T_{\mathrm{Q}}$ が $550^{\circ} \mathrm{G}$ 以下の低温に なるに従つて析出サイトが一般結晶粒界から粒界の三重 点一変化し析出物の数子急激に減少する.このことが固 溶炭素量の急激な増加と対応している。

W.Q 法の場合は AcC 法とは根本的に異なり, 炭化 物の析出サイトは結晶粒内になり，そのサイズは微細で 密度は高くなる。このように粒内に密度高く析出する微 細炭化物が存在するために炭素の析出のための必要拡散 距離が短くなり短時間の過時効処理で固溶炭素量は低下 することになる。 $T_{\mathrm{Q}}$ が $500^{\circ} \mathrm{C}$ 以下になると粒内炭化 物の数は少なくなり， $T_{\mathrm{Q}}$ が $400^{\circ} \mathrm{C}$ では粒界に析出し た炭化物が主体之なる。

Fig. 6 飞は $100^{\circ} \mathrm{C} \times 1 \mathrm{~h}$ の時効後の材質特性値に及 ぽす一次急冷開始温度の影響を示す。AcC 法に打忷る 一次急冷開始温度の材質に及洼寺影響は Fig. 5 亿示し た固溶炭素量の变化の様子とよく一致して拉り， $T_{\mathrm{Q}}$ が $675^{\circ} \mathrm{C}$ の時に降伏点は低く低降伏比になり 延性は高く なる．更に降伏点伸びはゼ口となつて加工用高張力鋼板 として優れた材質が得られる。 $T_{\mathrm{Q}}$ が $550^{\circ} \mathrm{C}$ 以下之低 くなると非時効性は失わ机材質は硬質化し延性も低くな る.

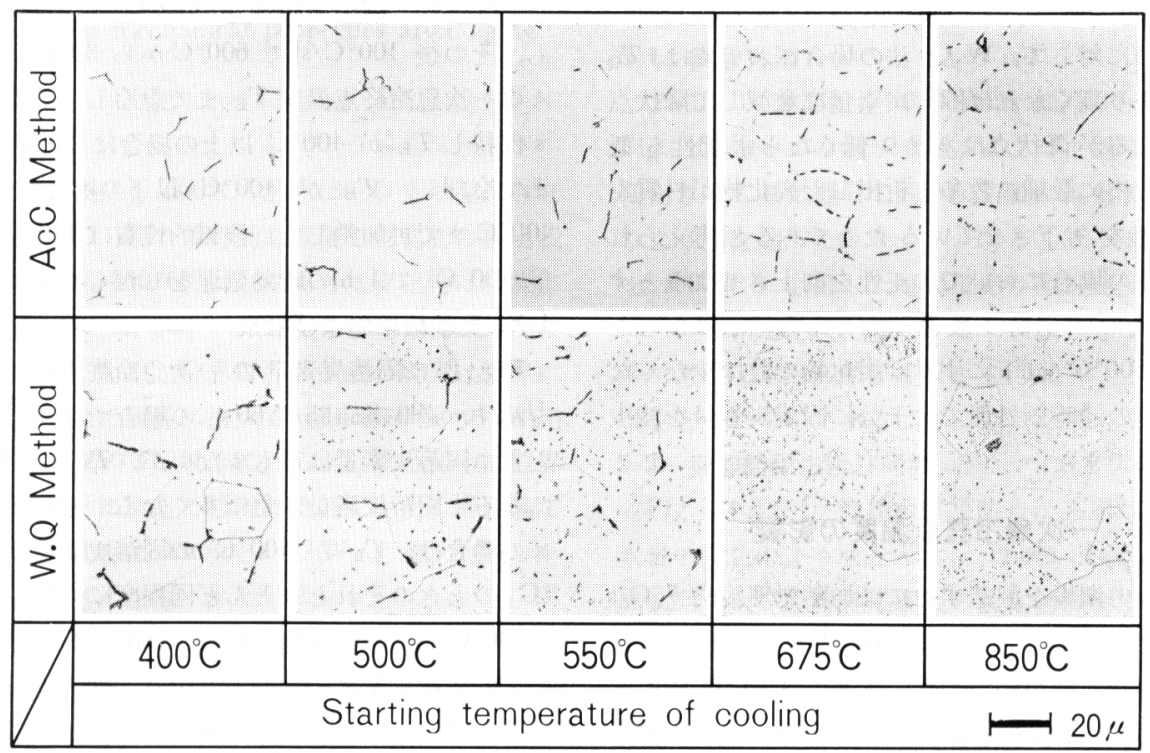

Photo. 2. Effects of the starting temperature $\left(T_{\mathrm{Q}}\right)$ of cooling on carbide precipitation. 


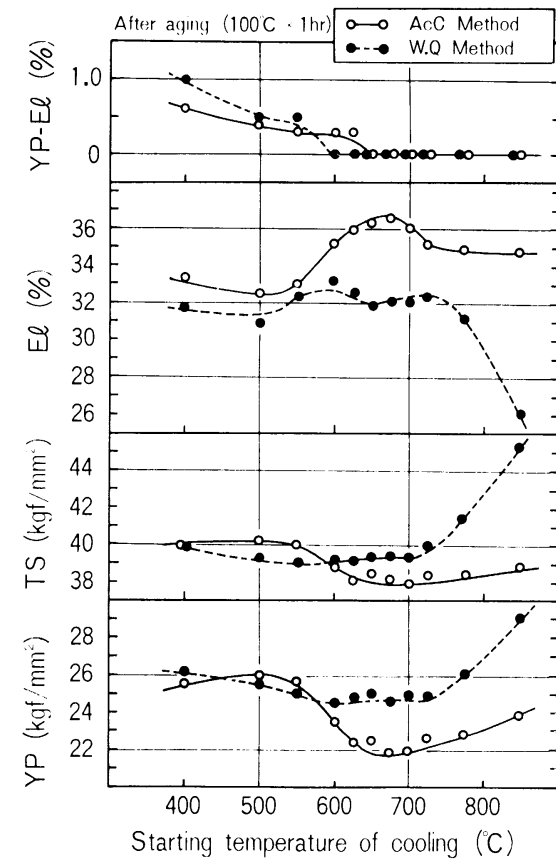

Fig. 6. Effects of the starting temperture $\left(T_{\mathrm{Q}}\right)$ of cooling on the mechanical properties after aging of $100^{\circ} \mathrm{C} \times 1 \mathrm{~h}$.

W.Q法の場命は $A C \mathrm{C}$ 泣の場公之は恨本似に異なり, Fig. 5 の固溶炭素量の変化との対忍が溥らぎ Photo. 2 亿示した粒内の微細な炭化物の影隌をらけて忉質特性 は変化する。AcC 法の場命は $T_{\mathrm{Q}}$ が $550^{\circ} \mathrm{C}$ より尚く なると固溶岑素量が急激に少なくなるとともに忉質特吽 は度くなるのに対して，W.Q 法の場命に拈いては $T_{\mathbf{Q}}$ が $500^{\circ} \mathrm{C}$ より高くなれば固溶岑素量は激減して降伏点 仪びは低くなるが降伏点はあまり低くならず延性も低 い.これは粒内に微細に数多く析出した岸化物が材質を 䃘質にし延性を劣下させているためであると考えられ る.W.Q 法の場合において加工性を向上させようとす ればこの粒内の炭化物の数を少なくしなければならな い. $T_{\mathrm{Q}}$ を $500^{\circ} \mathrm{C}$ 以下にすれば炭化物の数は少なくな るが，知時間の過時效处理では十分に固溶岑素是を減少 させることはできない。

\section{4. 一次急冷終点温度の影響}

加1:用高張力鋼板を製造するには均熱处理後約 $7^{\circ} \mathrm{C} / \mathrm{s}$ で $675^{\circ} \mathrm{C}$ まで徐冷し, 続いて約 $100^{\circ} \mathrm{C} / \mathrm{s}$ で急冷占るこ とが重要であることがわからた、本章では AcC 法に打 ける一次急冷終点温度の材質に及活与影響について調查 した結果を述べる.

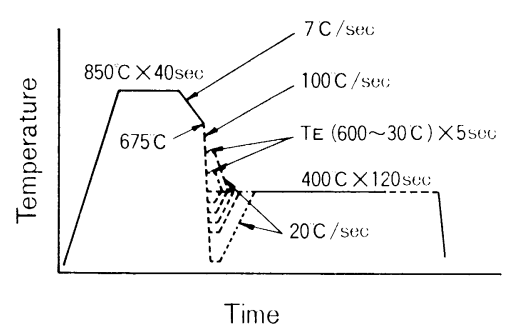

Fig. 7. Heat cycles for study on the effects of the end temperature $\left(T_{\mathrm{E}}\right)$ of cooling.

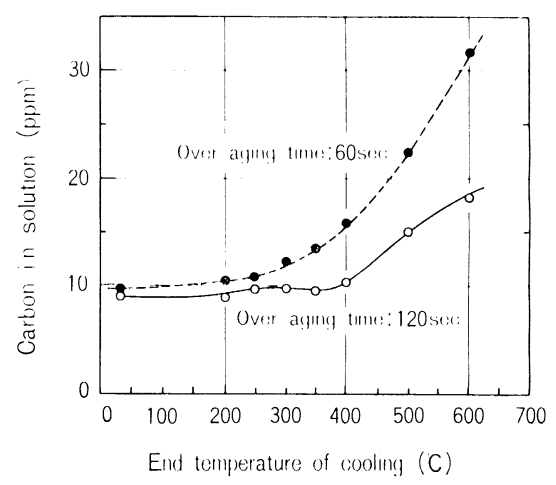

Fig. 8. Effect of the end tempcrature $\left(T_{\mathrm{E}}\right)$ of cooling on the amount of carbon in solution.

\section{$4 \cdot 1$ 実験方法}

験には Table 1 にふした鋼柲を $0.80 \mathrm{~mm}$ に冷间

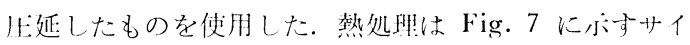
クルによつて一次急冷終少温庭 $\left(T_{\mathrm{E}}\right)$ の影響を調枯し た. $850^{\circ} \mathrm{C} て ゙ ~ 40 \mathrm{~s}$ 坞熱後 $675^{\circ} \mathrm{C}$ まで $7^{\circ} \mathrm{C} / \mathrm{s}$ で徐冷 し, その後 $100^{\circ} \mathrm{C} / \mathrm{s}$ で $600^{\circ} \mathrm{C}$ から $30^{\circ} \mathrm{C}$ までの間の雨 々の一次急冷終点温度 $T_{\mathrm{E}}$ まで总冷し, その齐温度で 5 $\mathrm{s}$ 保持し $T_{\mathrm{E}}$ が $400^{\circ} \mathrm{C}$ 以上の場命は $20^{\circ} \mathrm{C} / \mathrm{s}$ で $400^{\circ} \mathrm{C}$ まで泠却し， $T_{\mathrm{E}}$ が $400^{\circ} \mathrm{C}$ 以トの塨令は $20^{\circ} \mathrm{C} / \mathrm{s}$ で $400^{\circ} \mathrm{C}$ まで再加熱した，機械似性:質は $1.0 \%$ の調質た延 後 $100^{\circ} \mathrm{C}$ で $1 \mathrm{~h}$ の時効処理をしたものを調查した.

\section{$4 \cdot 2$ 実験結果および考察}

Fig. 8 に固溶炭素量の一次念冷終点温度に上る变化 を亦す，過時効時間が $60 \mathrm{~s}$ の埸命では $T_{\mathrm{E}}$ が $30^{\circ} \mathrm{C} の$ ときに固溶炭素量は最も少ないが， $T_{\mathrm{E}}$ が $300 \mathrm{C}$ 以上 になると固溶炭素量は急に多くなる。過時効時間が 120 $\mathrm{s}$ の場合は, $T_{\mathrm{E}}$ が $400^{\circ} \mathrm{C}$ の固溶岑素量は $T_{\mathrm{E}}$ が 30 ${ }^{\circ} \mathrm{G}$ のときのとれとほとんど闹程度に少なくなる。 $T_{\mathrm{E}}$ が $30^{\circ} \mathrm{C}$ のときは過時效時阊が $60 \mathrm{~s}$ から $120 \mathrm{~s}$ になつ ても固溶炭素量はそれ以上減少せず約 $9 \mathrm{ppm}$ の定侹 になつている. $T_{\mathrm{E}}$ が $400^{\circ} \mathrm{C}$ の場命は過洔効洔間が

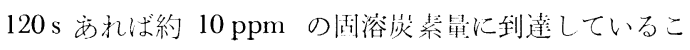




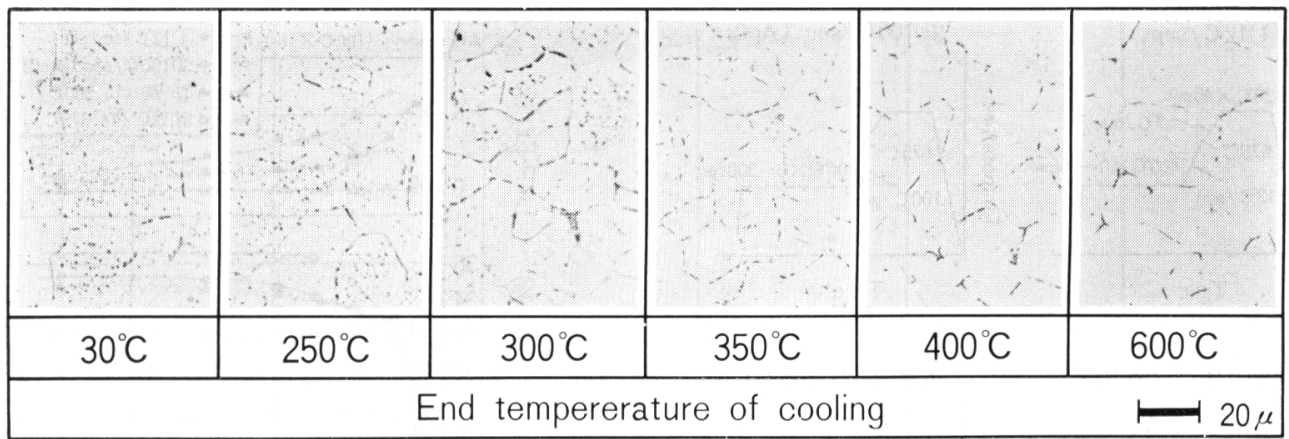

Photo. 3. Effect of the end temperature $\left(T_{\mathrm{E}}\right)$ of cooling on carbide precipitation.

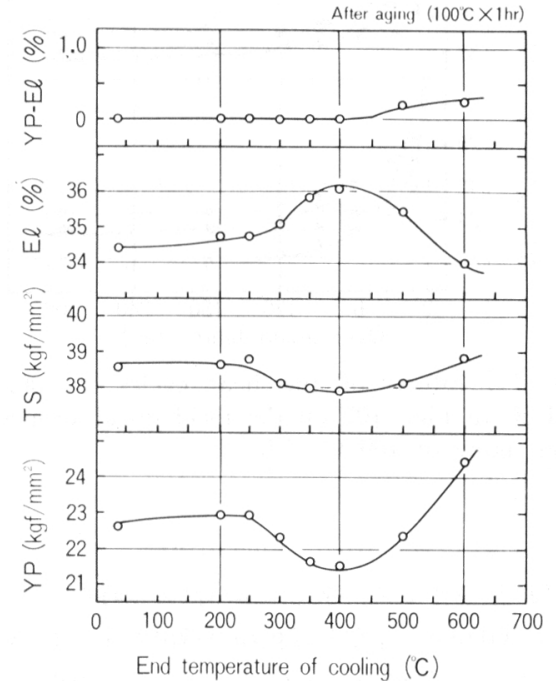

Fig. 9. Effects of the end temperature $\left(T_{\mathrm{E}}\right)$ of cooling on the mechanical properties after aging of $100^{\circ} \mathrm{C} \times 1 \mathrm{~h}$.

とがわかる.

Photo. 3 は $T_{\mathrm{E}}$ を $600^{\circ} \mathrm{C}$ から $30^{\circ} \mathrm{C}$ まで変化させ て $400^{\circ} \mathrm{C}$ で $120 \mathrm{~s}$ 間の過時効処理後の炭化物の析出状 態を示す。 $T_{\mathrm{E}}$ が $400^{\circ} \mathrm{C}$ 以上の場合は炭化物は粒界に 析出し $T_{\mathrm{E}}$ が $350^{\circ} \mathrm{C}, 300^{\circ} \mathrm{C}$ になると炭化物は粒内に も析出するようになる。粒界に近い領域の炭素は粒界に 片状に析出するので粒界に沿つて denuded zone が発 生する。 $T_{\mathrm{E}}$ が $250^{\circ} \mathrm{C}$ 以下になると一次冷却中に粒界 に析出する炭化物に加光て粒内に微細炭化物が密度高く 析出する. この状態は Photo. 2 の W.Q 法の $T_{\mathrm{Q}}$ が $675^{\circ} \mathrm{C}$ の場合に近くなる。

Fig. 9 は $100^{\circ} \mathrm{C} \times 1 \mathrm{~h}$ の時効後の降伏点，伸び, 降 伏点伸びに及ぼす $\mathrm{AcC}$ 法の一次急冷終点温度の影響を 示す. $T_{\mathrm{E}}$ が $500^{\circ} \mathrm{C}$ より高くなると Fig. 8 に示すよ らに固溶炭素量が多くなり，そのために降伏点，延性の
材質特性が劣下し降伏点伸びもゼロにはならなくなる。 逆に $T_{\mathrm{E}}$ が $250^{\circ} \mathrm{C}$ 以下になると固溶炭素量は少なくな り降伏点伸びはゼロになるが，W.Q 法の場合と同様に 粒内の微細炭化物の影響をらけて降伏点は高く伸びは低 くなる。 $T_{\mathrm{E}}$ を $400^{\circ} \mathrm{C}$ にすると降伏点は低く伸びは高 くなり同時に降伏点伸びもゼロになり優れた加工用高張 力鋼板が得られる.これは $T_{\mathrm{E}}$ を $400^{\circ} \mathrm{C}$ にすれば固溶 炭素量を低減する効果はW.Q法並にまで発揮できると 同時に材質特性を劣下させる粒内の微細炭化物の生成を 害のない程度に亦で抑壳ることができるためであると考 えられる11).

\section{5. 連続焼鈍途中での岸素の挙動と材質}

連続焼鈍方法の特徵を一層明らかにするために，焼鈍 途中での固溶炭素量, 炭化物の析出挙動を各種の熱サイ クルに颃いて調べた。機械的性質は $1.0 \%$ の調質压延後 $100^{\circ} \mathrm{C}$ で $1 \mathrm{~h}$ の時効処理をしたものを調查した.

\section{$5 \cdot 1$ 実験方法}

Table 1 の鋼板を $0.80 \mathrm{~mm}$ に冷間圧延し，去れを Fig. 10 の 4 つの熱サイクルによつて過時効処理時間を 変化させて熱処理して固溶炭素量, 炭化物, 材質の変化 のようすを調べた。サイクル (I) と (II)は一次急冷終点温度 を $400^{\circ} \mathrm{C}$ に制御したものであり冷却速度を $12^{\circ} \mathrm{C} / \mathrm{s}$ と $100^{\circ} \mathrm{C} / \mathrm{s}$ に違光てある.サイクル(III) (IV) W.Q法のも のであつて水冷開始温度 $T_{\mathrm{Q}}$ を $550^{\circ} \mathrm{C}$ と $675^{\circ} \mathrm{C}$ の二水 準をとつたものである。

\section{$5 \cdot 2$ 実験結果および考察}

Fig. 11 に一次急冷の終了時点から過時効中の固溶炭 素量の変化の上うすを示す. Photo. 4 に湠化物の生 成初期特よび過時効処理後の炭化物の析出状態が熱サイ クルによつて変化するようすを示す。

$\mathrm{AcC}$ 法では $400^{\circ} \mathrm{C}$ に終点制御して $100^{\circ} \mathrm{C} / \mathrm{s}$ で泠却 するので約 $80 \mathrm{ppm}$ の多量の過飽和炭素量をもちつつ, 既に結晶粒界には固溶炭素の析出場所となる約 $2 \mu$ の炭 


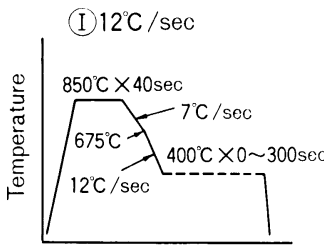

Time

(II) W.Q ( $\left.T_{0}: 550 \mathrm{C}\right)$

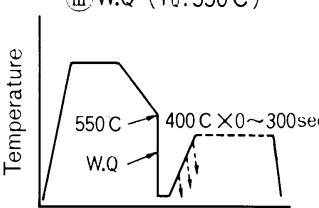

Time
(II) $100^{\circ} \mathrm{C} / \mathrm{sec}(\mathrm{AcC})$

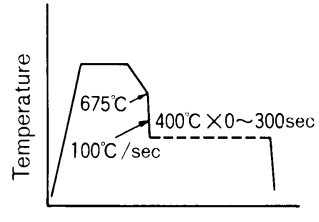

Time

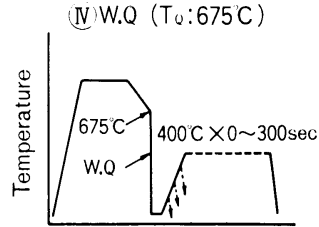

Time
Fig. 10. Heat cycles for study on the changes of carbon precipitation during heat treatment.

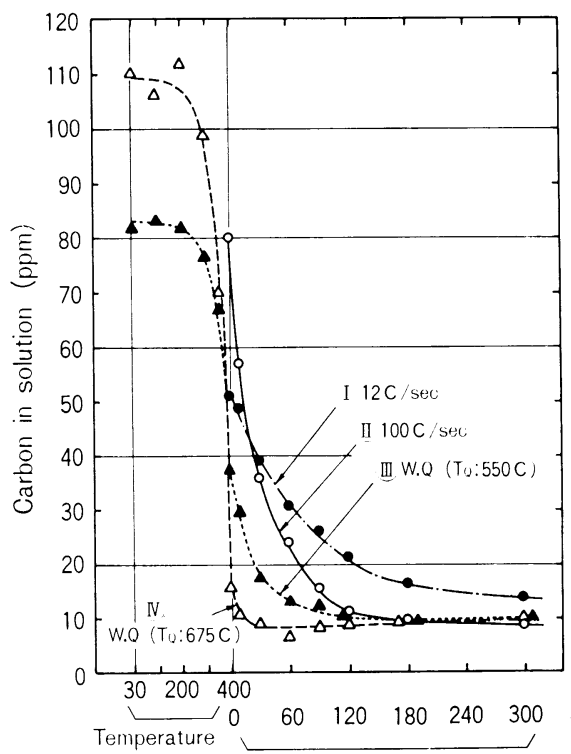

during reheating (C) Over aging time at $400^{\circ} \mathrm{C}(\mathrm{sec})$

Fig. 11. Effect of heat cycles on the amount of carbon in solution.

化物が点列状に存在している状態で過時効処理に入る. 従つて $120 \mathrm{~s}$ の過時効処理で W.Q法の場合と同じ固溶 炭素量にまで低減する。

サイクル】では冷却速度が $12^{\circ} \mathrm{C} / \mathrm{s}$ と遅いので固溶炭 素は約 $50 \%$ 以上析出してしまい, 冷却の終点の時点で 約 $50 \mathrm{ppm}$ が存在するにとどまる. 更にセメンタイトは 約 $10 \mu$ の大きさで結晶粒界の三重点に析出した状態に あるので $300 \mathrm{~s}$ の過時効時閒でも固溶炭素量は十分に低

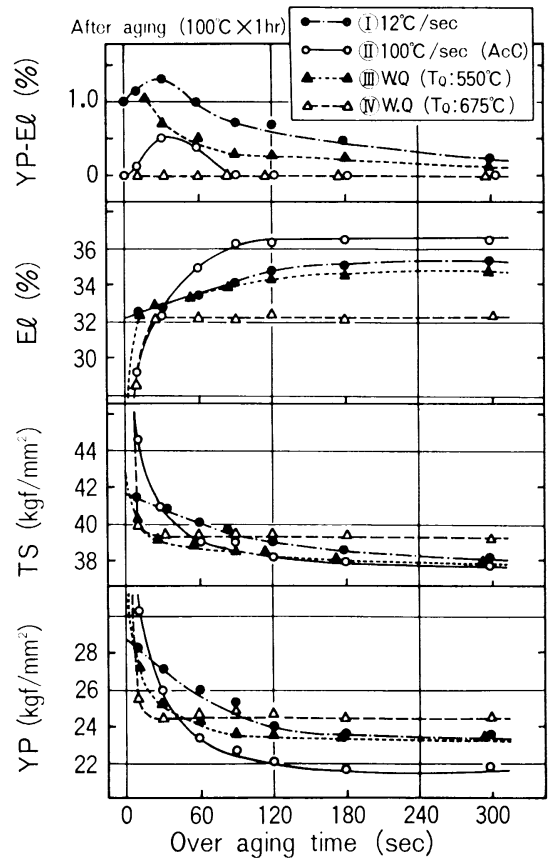

Fig. 12. Effects of the heat cycles (I), (II), (III) and (VV) in Fig. 10) on the mechanical properties after aging of $100^{\circ} \mathrm{C} \times 1 \mathrm{~h}$.

下していない.

W.Q 法のサイクル、何では水冷㨁後の時点で沽溶炭素 量は約 $100 \mathrm{ppm}$ 存在し炭化物の析出の仕 $j$ も AcC 法 の場合之異なり Photo. 4-C に示すように炭化物はほ之 んどみられない。しかし過時効温度の $400^{\circ} \mathrm{C}$ まで昇温 する途中で固溶炭素量は $15 \mathrm{ppm}$ に亦て激減し，同時に Photo. 4-D に示すように粒内に約 $0.4 \mu$ の微細な炭化 物が極めて密に析出してしまつている。 その後は $20 \mathrm{~s}$ の短時間の過時効で固溶炭素最は約 $10 \mathrm{ppm} の 一$ 定优に 達してしまう。

$\mathrm{W} . \mathrm{Q}$ 法のサイクル(III) するので水冷直後でも Photo. 4-A にみられるように約 $10 \mu$ のセメンタイトが粒界の三重点に既にみられる. 固溶炭䒺量は約 $80 \mathrm{ppm}$ あるが，その後の邽加熱の途中 に約 $0.5 \mu$ の炭化物となつて粒内に析出する. しかし 炭化物の密度はかなり低くなるので必要過侍效侍閒は AcC 法とほぼ同じになる。

Fig. 12 は 4 つの熱サイクル (I)(III) IV)に拉いて時㕮後 の材質が過時効時間によつてどのように変化するかを示 す. 冷却速度の遅いサイクル(1)では一次冷却直後の時点 でFig. 11 に示したように固溶炭素量は最も少ないの で降伏点も低く伸びも比較的大きいものと思われる。し 


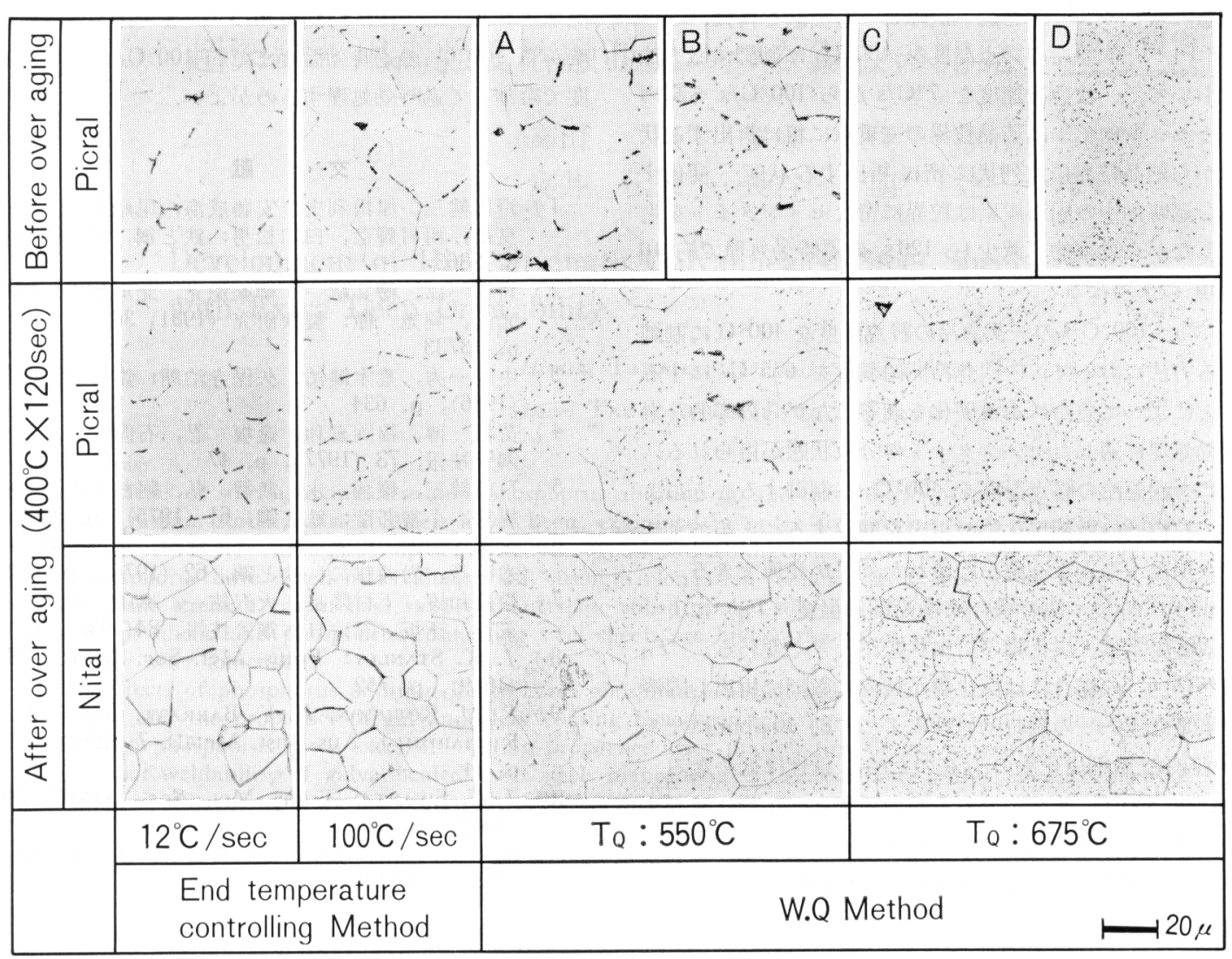

Photo. 4. Effects of the heat cycles (II), (II), (III) and (IV) in Fig. 10) on carbide precipitation during heat treatment. A and C: immediately after water quenching. B and D: immediately after reheating to $400^{\circ} \mathrm{C}$.

かしその後の過時効にお活る材質特性の回復が少ないま まに $180 \mathrm{~s}$ で一定值に収束する.

サイクルIII AcC 法では過時効時間とともに急速に 材質は回復し約 $120 \mathrm{~s}$ で一定值に達する。しかも4つの サイクルの内では最も降伏点が低く軟質で伸びが最も大 きい材質を得ることができる。降伏点は他の 3 つのサイ クルの場合に比べて $2 \mathrm{kgf} / \mathrm{mm}^{2}$ 以上低く軟質になり, 伸びも 2 ～ $4 \%$ 高い值をもつことがでさる. 屯た，降 伏点伸びるゼロに抑光ることができる。これらは粒界に 比較的密に析出したセメンタイトによつて固溶炭素量を 効率的に減少させることができることと，材質を硬質に し，乙か子延性を劣下させる粒内に密に析出する炭化物 がないためであると考劣れる。

W.Q 法のサイクルIVD場合は固溶炭素量の変化に対 応して材質は急速に回復をはじめ 20 30s の過時効時 間で一定值に収束する。従つて必要過時効時間はかなり 短くてもよいが降伏点は高く硬質で延性は低い。これは 結晶粒内に密に析出している炭化物のためであると考党
られる、W.Q 法のサイクル而はサイクル付での材質特 性を向上させるために $T_{\mathrm{Q}}$ を下げて $550^{\circ} \mathrm{C}$ にしたもので あるが Photo. 4 に示すように結晶粒内の微細炭化物の 生成は防止できず材質の向上はそれほど大きくはない。 また，サイクル(IIIではサイクル(III)りも短い過時効時間 で固溶炭素量は少なくなるが降伏点伸びはゼロになつて いない。この理由は明らかでないが, 粒内の微細炭化物 とやや大きい粒界のセメンタイトの存在する両者におい ては調質圧延の効果に差異があるためであろら。やや大 きなセメンタイトが不均一に存在する場合には降伏点伸 びが抑觉られやすいのは, 局所的な応力集中が生じるこ とや，不均一変形によつて可動転位が残存することによ る可能性が考方られる。

\section{6. 結言}

加工用高張力鋼板を連続焼鈍によつて製造する場合の 熱サイクル条件と材質の関係について調查した. 特に材 質に大きな影響を与古る固溶炭素量および炭化物の析出 
状態の変化のようすを調べ次のような結論を得た。

（1）一次急冷の終点温度を $400^{\circ} \mathrm{C}$ 飞制御するJj法 において，一次急冷速度を $7^{\circ} \mathrm{C} / \mathrm{s}$ から $100^{\circ} \mathrm{C} / \mathrm{s}$ 一离め るとセメンタイトは結晶粒界の三重点に粗に析出する状 態から結晶粒界に点列状に密に析出与る状態一変化す る. 過時効中の固溶炭素は粒界飞密なセメンタイトを生 成しながら効率的に減少し $120 \mathrm{~s}$ の過時効処理で約 10 ppm にまでなる。

(2) $100^{\circ} \mathrm{C} / \mathrm{s}$ の一次急冷の終点温度を $400^{\circ} \mathrm{C}$ に制御 する方法に沶いて，一次急冷開始温度を $675^{\circ} \mathrm{C}$ にする ことによつて急冷による硬化を问避しながら效辩的な過 時効処理に適したセメンタイトの分散状態が得られる.

更に一次急冷の終点温度を $400^{\circ} \mathrm{C}$ 飞制御することによ つて䊉内への微細炭化物の析出を回避することができ延 性を損ならことなく急冷の優れた効果が発揮できる。

（3）W.Q 法の場合は急冷開始温度（ $\left.T_{\mathrm{Q}}\right)$ によつ て固溶炭素量と炭化物の析出状態が大きく变わる. $T_{\mathbf{Q}}$ が $675^{\circ} \mathrm{C}$ の場合には炭化物が䊀队微細に析出し固浴 荻素量は $20 \mathrm{~s}$ の過時效処理によつて約 $10 \mathrm{ppm}$ になる が䊉内の微細炭化物の存在のために延性は低くなる。 $T_{\mathrm{Q}}$ を $550^{\circ} \mathrm{C}$ までトげると粘内の微紐炭化物は減少す るが十分な延性の问復にはいたらない。

（4）非時效性でから加下:性のよい鋼板を得るための
熱サイクルとしては，均熱後 $675^{\circ} \mathrm{C}$ まで徐冷しその温 度から $400^{\circ} \mathrm{C}$ の過時效温度まで約 $100^{\circ} \mathrm{C} / \mathrm{s}$ の冷却速 度で泠却して過時効处理与るのがよい。

\section{交献}

1 ) 戸田健三，原田利夫，安滕成海，尼俆康二，勝行 良碩，西村輝彦，田田松男：鉄と鋼，61 (1975)， p. 2863

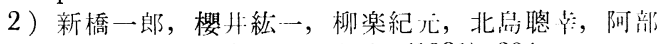
光延, 利光 徽: 製鉄研究 (1981) 304, p. 13733

3）中阙一秀，荒小健治，久保寺治朗：鉄と鋼，62 (1976), p. 634

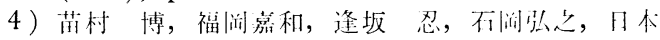
鋼管技報， 73 (1977), p. 47

5 ）开旧健三, 権滕永, 武智弘, 阿部光延, 上原 規正，小宫邦彦：鉄と鋼，61 (1975)，p. 2363

6 ）久保寺治朗, 中阔一秀, 旒个健治, 渡辺馨, 西 本昭彦，岩瀬耕二：鉄と铜，62 (1976), p. 624

7 ) 松滕和雄, 一下村降食, 大㳄紿一, 奥山健, 木卜 正行, 逢坂 忍: 月术銅管技晁, $84(1980)$, p. 14

8 ) J. K. Stanley: Trans. Met. Soc. AIME, 185 (1949), p. 752

9 ) P. M. Robinson, $K . V$. Barratt, and $P . N$. Richards: J. Aus. Inst. Metals, 7 (1962), p. 34

10) J. C. Swartz: Trans. Met. Soc. NIME, 239 (1967), p. 68

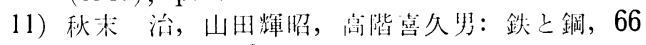
(1980), $\$ 1126$ 